\title{
Förvärvsarbete och försörjning
}

\author{
BENGT FUR $\mathrm{KER}$
}

Människor försörjer sig i hög grad genom förvärvsarbete. Ingen kan emellertid förvärvsarbeta hela livet-och en del kan det aldrig-vilket förutsätter andra överlevnadsmöjligheter. Sådana finns t. ex. via familjen, egen förmögenhet, välfärdsstaten eller privata försäkringar. Förvärvsintensiteten, som länge varit hög i Sverige, har sjunkit rejält under 1990-talet. Av övriga försörjningskällor är det bara familjen och välfärdsstaten som kan spela någon större roll. Med de däliga statsfinanserna vältras dock bördan allt mer över på familjer och individer. Vi kommer därför kanske att få se snabbt växande sociala klyftor och ökad fattigdom.

I dagens utvecklade samhällen erhåller människor till stor del sitt uppehälle genom vad vi brukar kalla förvärvsarbete. Eftersom inte hela befolkningen kan förvärvsarbeta måste det emellertid finnas andra försörjningsmöjligheter - om vi utgår från att samtliga ska försörjas. I själva verket måste alla - åtminstone under vissa perio-

Bengt Furåker är professor i sociologi vid Göteborgs universitet men har tidigare länge varit verksam både vid Lunds och vid Umeå universitet. Hans forskning är främst inriktad på frågor kring arbetsmarknad, arbetsmarknadspolitik, välfärdsstat och offentlig sektor. der av sina liv - överleva via något annat än arbete. Det är framför allt familjen och välfärdsstaten som utgör de funktionella alternativen.

Internationellt sett har arbetskraftsdeltagandet och förvärvsintensiteten länge legat på höga nivåer i Sverige liksom i de övriga nordiska länderna. Den främsta anledningen till detta är att kvinnorna i så stor utsträckning har förvärvsarbete. I bilden ingår dock att de nordiska kvinnorna - med undantag för finskorna - i hög grad arbetar deltid. Många kan ha ett deltidsjobb som 
inte räcker vare sig till att försörja en familj eller ens till den egna försörjningen. Arbetet blir snarast ett komplement till inkomster som övriga familjemedlemmar eller välfärdsstaten bidrar med. Ändå innebär det att fler individer får egna pengar att röra sig med.

Föreliggande uppsats kommer att beskriva några huvuddrag $\mathrm{i}$ de arbetsmarknadsförändringar som under 1990-talet ägt rum i Sverige. Dessa förändringar har medfört att massor av arbetstillfällen försvunnit, att arbetslösheten stigit dramatiskt och att många lämnat arbetskraften. Det är följaktligen avsevärt färre som i dag tjänar sitt uppehälle genom eget arbete än för bara några år sedan. I slutet av uppsatsen kommer jag att diskutera konsekvenserna därav för befolkningens försörjning. Till att börja med ska jag inventera olika möjligheter för människor att överleva utan att förvärvsarbeta.

\section{Försörjningskällor}

Hur får nu de som inte förvärvsarbetar (kan förvärvsarbeta) sitt uppehälle? I de ekonomiskt avancerade länderna (resonemanget begränsas här till dessa) föreligger ett antal alternativ och ett första sådant är familjen. Föräldrar förutsätts som bekant försörja sina minderåriga barn, men familjeinstitutionens försörjningsansvar sträcker sig normalt längre än så. Ansvaret kan också avse make/maka, vuxna barn och andra släktningar, t.ex. gamla föräldrar. De konkreta lösningarna varierar, men det existerar förväntningar och ett socialt tryck på familjen att finnas till hands som försörjningsgarant. Det socioekonomiska systemet tillhandahåller normer som mer eller mindre tydligt och mer eller mindre motsägelsefullt definierar familjebandens räckvidd. Normerna är emellertid oupphörligen föremål för diskussion, omprövning och modifiering.

För det andra är det möjligt för människor att överleva via egen förmögenhet. Den som har ekonomiska tillgångar att leva på tillåts göra det. Hur resurserna har förvärvats verkar ha mindre betydelse - förutsatt att de är lagligt förvärvade. Det kan t.ex. handla om arv, sparande, vinster av företagande eller spelvinster. Ingenting hindrar att individer med egna tillgångar avstår från att förvärvsarbeta. Detta hade i princip varit svårt i t.ex. Sovjetunionen, där arbetsföra människor förutsattes försörja sig genom eget arbete (se Författning...1980, artikel 60 ).

Självfallet är det få personer som i dagens Sverige kan leva på sin förmögenhet utan att ha ett inkomstbringande arbete. Man bör komma i håg att kapitalister ofta är verksamma som arbetande företagsledare. Genom sitt ägande kan sådana personer få en ersättning som inte direkt hänför sig till deras arbetsinsatser, men de tillhör icke desto mindre kategorin förvärvsarbetande.

En tredje lösning är försörjning via välfärdsstaten. I många länder erhåller stora delar av befolkningen sitt uppehälle genom det allmännas försorg. Den offentliga sektorns ansvar och insatser som försörjningskälla är omstridda. Den politiska diskussionen handlar i hög grad just om välfärdsstatens spelregler och risken för missbruk av förmåner. Vissa av välfärdsstatens kriterier har dock varit relativt enkla att definiera. Folkpensionen i Sverige kan tas som exempel (se t.ex. Palme 1990; Olofsson 1993). 


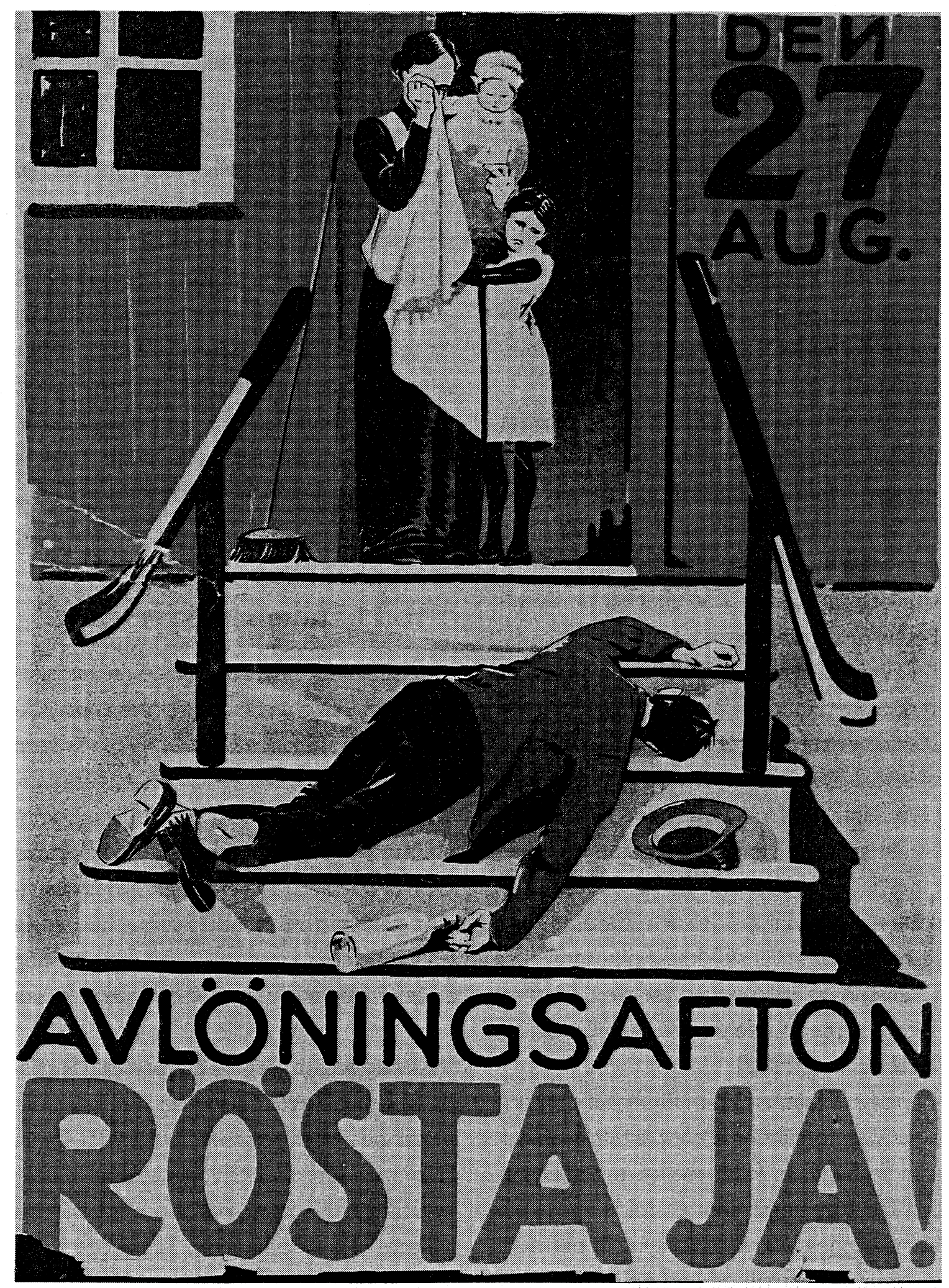

Furåker - Förvärvsarbete och försörjning 
Den innebär att gamla människor inte behöver stå till arbetsmarknadens förfogande eller vara beroende av att släktingar tar hand om dem. Genom att pensionen betalas ut när man uppnått en viss ålder är risken för missbruk försumbar. Sa fort andra kritierier ska beaktas (tidigare inkomst, behov eller annat) blir det hela mer komplicerat. En jämförelse mellan olika länder visar på avsevärda skillnader i pensionssystemens konstruktion.

Välfärdsstatens regelverk definierar ett antal omständigheter vilka betraktas som "giltigt förfallı att slippa förvärvsarbete och berättigar till olika typer av stöd. Det kan vara fråga om att människor anses ha "gjort sittu och får gå i pension eller att de tillfälligtvis är oförmögna att arbeta såsom vid sjukdom eller studier. Den senare typen av verksamhet innebär ju inte precis arbetsoförmögenhet $i$ ordets vanliga bemärkelse men förutsätter ändå att individen under en period inte kan förvärvsarbeta. Över tid och länder emellan finns det en stor variation beträffande kriterierna för att få välfärdsstatens stöd. Mångfalden av välfärdsstatliga lösningar finns väl skildrad i den samhällsvetenskapliga litteraturen (se t.ex. Castles 1989; Esping-Andersen 1990; Ginsburg 1992; Kolberg 1992).

Ett fjärde sätt att få sin försörjning utgörs av privata försäkringar eller avtalslösningar som förhandlats fram mellan arbetsgivare och fackföreningar eller enskilda individer. Många av dessa arrangemang utgör närmast ett komplement till den offentliga sektorns åtaganden. Exempelvis är ju inte i Sverige privata pensionsförsäkringar en ersättning för folkpensionen och ATP-systemet utan de kommer därutöver. Forskningen kring välfärdsstaten har allt mer försökt beakta kombinationerna mellan offentliga och privata försäkringssystem (se t.ex. vissa av bidragen i Kolberg 1992).

Det finns naturligtvis ytterligare sätt på vilka människor får sitt uppehälle i den ekonomiskt utvecklade världen. Somliga livnär sig på brottslig verksamhet; vissa överlever genom att tigga och andra återigen genom att ta del av välgörenhetens allmosor. Dessa alternativ har i vart fall inte i Sverige någon stor utbredning, men de kan tänkas fä ökad betydelse om det blir svårare för folk att skaffa sig vanligt förvärvsarbete.

\section{Vad händer i Sverige i dag?}

Avsikten är att i det följande ge en översiktlig presentation av de senaste årens utveckling på arbetsmarknaden. Utgångspunkten är att jämföra 1990, 1993 och 1994. Startåret 1990 rådde det fortfarande högkonjunktur och arbetsmarknaden kan beskrivas som överhettad. Därefter har förändringarna gått mycket snabbt. Sverige har aldrig tidigare under efterkrigstiden haft så hög arbetslöshet som under 1990-talets första hälft.

Underlaget utgörs här av data från Statistiska centralbyråns arbetskraftsundersökningar och avser personer i åldern 16-64 år. Från och med 1993 genomförs datainsamlingen på ett något annorlunda sätt än tidigare ("De svenska..." 1993). Följden är att förändringarna på arbetsmarknaden mellan 1990 och 1993 eller 1994 kanske överskattas en smula. Det rör sig om ganska små skillnader, men där det har varit möjligt för mig har jag utgått från de justerade uppgif- 
ter som Statistiska centralbyrån räknat fram.

Den ökade arbetslösheten under senare år sammanhänger med en betydande minskning av sysselsättningen (tabell 1). Antalet förvärvsarbetande sjönk med över en halv miljon personer mellan 1990 och 1994. Raset hade nått full styrka 1993 men fortsatte i viss utsträckning i de flesta näringar under 1994. Tillverkningsindustrin är den näringsgren som fått vidkännas den klart största minskningen. I mitten av 1960-talet var en tredjedel av de förvärvsarbetande verksamma inom tillverkningsindustrin; år 1994 var det inte ens en femtedel.

Andra näringsgrenar som uppvisar kraftiga nedgångar är "byggnadsindustri«, ,handel, restaurang- och hotellverksamhet" samt "offentlig förvaltning och andra tjänster". Den sistnämnda kategorin rymmer inte bara offentliganställda - även om en stor majoritet är anställda i stat eller kommuner - utan här förekommer också privata tjänsteverksamheter. Samtidigt finns det åt- skilliga offentliganställda i somliga av de övriga näringarna, t.ex. inom nsamfärdsel, post och telekommunikationer». I arbetskraftsundersökningarna görs också en annan indelning som skiljer mellan företagare, medhjälpande familjemedlemmar och olika kategorier anställda (statligt, kommunalt och enskilt). Om vi utgår från den indelningen finner vi att de offentligt anställda blev drygt 250000 personer färre mellan 1990 och 1994. Minskningen beror emellertid delvis på bolagiseringar.

I tabell 1 redovisas också det genomsnittliga antalet veckoarbetstimmar för den aktuella perioden. Även här finner vi en mycket kraftig skillnad mellan 1990 och 1994; det handlar om närmare tjugo miljoner timmar i veckan. Relativt sett är nedgången faktiskt större beträffande arbetstimmar än i fråga om förvärvsarbetande individer. Ändå har det skett en viss återhämtning mellan 1993 och 1994 - väl att märka utan att sysselsättningen har ökat. Innebörden i detta är förstås att de förvärvsarbe-

\section{Tabell 1}

Sysselsatta och veckoarbetstimmar 1990, 1993 och 1994 samt förändring 1990-94. Tusental och miljontal.

1990* $\quad 1993 \quad 1994 \quad \begin{array}{r}\text { Förändring } \\ 1990-94\end{array}$

\section{Sysselsatta}

(tusental)

4449

män

2313

kvinnor

2134

$1938 \quad 1911 \quad-223$

Veckoarbetstimmar

(miljontal)

\section{1,6}

120,5

122,2

$-19,4$

män

* Siffrorna för 1990 är justerade efter de förändringar som gjorts i arbetskraftsundersökningarna fro m 1993.

Källor:»Sysselsättning och...« 1993 och Arbetskraftsundersökningen 1993 och 1994. 
tande i genomsnitt jobbade mer det senare året. Vi kan notera en ökning av övertiden $i$ samband med att konjunkturen återhämtat sig.

Givet den korta tid det rör sig om får sysselsättningsnedgången $i$ landet betecknas som dramatisk. Det är framför allt de mansdominerade industriella delarna som har krympt. Konsekvensen borde bli en ökad arbetslöshet och en högre sådan bland män än bland kvinnor. Detta har också inträffat. Efter den svenska kronans fall i november 1992 har industrin fätt uppleva en avsevärd konjunkturuppgång, men effekterna på sysselsättningen har varit måttliga. Det verkar vara lättare att trampa ner i arbetslöshetsträsket än att ta sig ur det.

Sverige som under efterkrigstiden varit känt i omvärlden för sin förmåga att hålla arbetslösheten nere (se t.ex. Furåker 1991) har snabbt förvandlats till ett normaleuropeiskt massarbetslöshetsland. I tabell 2 ser vi bl.a. hur de relativa arbetslöshetstalen skjutit i höjden. Och det är männens siffror som ökat mest. År 1990 låg män och kvinnor på nästan samma nivå; år 1993 var läget ett helt annat - männens arbetslöshetstal var nästan en och en halv gånger högre än kvinnornas. Det är naturligtvis nedgången inom industrin och byggnadssektorn som ligger bakom denna utveckling. Senare har det skett en smärre utjämning mellan könen, men den allmänna nivån har inte nämnvärt förändrats.

Tabell 2 visar också sysselsättningsintensiteten, dvs. andelen sysselsatta av befolkningen i yrkesaktiv ålder. Som vi kunde vänta oss efter att ha tagit del av tabell 1 rör det sig om betydande minskningar. För männen handlar det om en nedgång med drygt 12 och för kvinnorna med nästan 10 procentenheter mellan åren 1990 och 1994.

Om arbetslösheten stiger skulle man kunna tänka sig att arbetskraftsdeltagandet

Tabell 2.

Relativa arbetslöshetstal, sysselsättningsintensitet och relativa arbetskraftstal 1990, 1993 och 1994. Procent.

$\begin{array}{lrrr} & 1990 * & 1993 & 1994 \\ \text { Relativa arbetslöshetstal } & 1,6 & 8,2 & 8,0 \\ \text { män } & 1,7 & 9,7 & 9,1 \\ \text { kvinnor } & 1,6 & 6,6 & 6,7 \\ & & & \\ \text { Sysselsättningsintensitet } & 82,4 & 72,6 & 71,4 \\ \text { män } & 84,4 & 73,0 & 72,2 \\ \text { kvinnor } & 80,3 & 72,1 & 70,7 \\ & & & \\ \text { Relativa arbetskraftstal } & 83,8 & 79,1 & 77,6 \\ \text { män } & 85,8 & 80,9 & 79,4 \\ \text { kvinnor } & 81,6 & 77,2 & 75,7 \\ \text { * Siffrorna för 1990 ärjusterade efter de förändringar som gjorts i arbetskraftsundersökningarna fro.m. } 1993 . \\ \text { Källor:»Sysselsättning och...《 1993 och Arbetskraftsundersökningen } 1993 \text { och 1994. }\end{array}$


ändå ligger kvar på samma nivå, eftersom arbetskraften ju är summan av sysselsatta och arbetslösa. Minskningen i antalet sysselsatta skulle motsvaras av en ökning i arbetslösheten. Därmed skulle den andel av befolkningen som befinner sig i arbetskraften förbli konstant. Så har dock inte alls varit fallet. De relativa arbetskraftstalen har sjunkit påtagligt vilket också framgår av tabell 2.

Både männens och kvinnornas arbetskraftsdeltagande har glidit ner under 80procentsstrecket (och i kvinnornas fall ett gott stycke under). Den stolta trenden med ständigt ökande relativa arbetskraftstal för de svenska kvinnorna är med andra ord bruten. För männens del har utvecklingen pekat nedåt under en längre tid, men det är först på 1990-talet som nivån på arbetskraftsdeltagandet verkligen har rasat.

Med den minskade sysselsättningen har arbetslösheten alltså tagit snabba språng uppåt och andelen personer utanför arbetskraften har likaså stigit rejält. En konsekvens av recessionen är att folk i mindre utsträckning sökt sig ut på arbetsmarknaden över huvud taget. I absoluta tal mätt är ökningen av antalet personer utanför arbetskraften klart större än ökningen av arbetslösheten. År 1994 var det genomsnittliga antalet arbetslösa var 265000 fler än 1990 (se tabell 4) samtidigt som antalet personer utanför arbetskraften var ca 410000 fler (tabell 3).

Vad gör alla människor i yrkesaktiv ålder

Tabell 3

Personer ej i arbetskraften 1990, 1993 och 1994 samt förändring 1990-94. Tusental.

$\begin{array}{lrrrr} & 1990^{*} & 1993 & 1994 & \begin{array}{r}\text { Förändring } \\ 1990-94\end{array} \\ & 820 & 1141 & 1230 & +410 \\ \text { Totalt } & 358 & 529 & 574 & +216 \\ \text { män } & 462 & 612 & 656 & +194 \\ \text { kvinnor } & & & & \\ \text { därav } & 343 & 489 & 512 & +169 \\ \text { studerande } & 171 & 248 & 260 & +89 \\ \text { män } & 172 & 241 & 252 & +80 \\ \text { kvinnor } & 115 & 107 & 102 & -13 \\ & 4 & 3 & 2 & -2 \\ \text { hemarbetande } & 111 & 104 & 100 & -11 \\ \text { män } & & & & \\ \text { kvinnor } & & & & \\ & & & 397 & +117 \\ \text { pensionerade (inkl } & & 361 & 188 & +51 \\ \text { förtidspensionärer), } & & & \\ \text { arbetsoförmögna } \mathrm{m} \text { fl } & 280 & 174 & 189 & +65 \\ \text { män } & 137 & 188 & 209 & \\ \text { kvinnor } & 144 & & & \end{array}$

* Siffrorna för 1990 är inte justerade efter de förändringar som gjorts i arbetskraftsundersökningarna fr.o.m. 1993.

Källor:»Sysselsättning och...« 1993 och Arbetskraftsundersökningen 1993 och 1994. 
vilka befinner sig utanför arbetskraften? I arbetskraftsundersökningarna görs en indelning av dessa individer efter shuvudsaklig verksamhetu. Tyvärr är den bild vi får inte alldeles tillfredsställande, eftersom det på vissa punkter rör sig om väl grova kategorier och därtill har det genomförts förändringar i dessa efter 1990. Tabell 3 erbjuder dock information som tillåter jämförelser över tid, men jag har då fått göra några sammanslagningar. Problemet gäller framför allt vad som finns bakom rubriken "pensionerade (inkl. förtidspensionärer), arbetsoförmögna m.fl.». Dessa kategorier går inte att särskilja och rubriken döljer också en mindre grupp som inte ingår i den svenska arbetskraften eftersom den arbetar utomlands. Hur som helst ser vi att de pensionerade, arbetsoförmögna m.fl. tillsammans ökade kraftigt mellan 1990 och 1994, även om det inte går att närmare specificera vari förändringen består. Vi vet från andra källor att antalet nybeviljade förtidspensioner steg markant under 1992 och 1993 - men bara för att sedan minska igen under 1994 (se «Nybeviljade förtidspensioner..." 1995). Likväl verkar beståndet av förtidspensionärer ha fortsatt att stiga ("Förtidspensioner...« 1995).

Vad som emellertid framgår klart i tabell 3 är att antalet studerande blivit avsevärt fler. Ökningen uppgår till ungefär 170000 personer på fyra år. En del av dessa befinner sig i arbetsmarknadspolitiska åtgärder såsom arbetsmarknadsutbildning och arbetslivsutveckling (ALU). Slutligen innehåller tabellen ytterligare en kategori bestående av dem som huvudsakligen ägnat sig åt hemarbete. Till skillnad från de övriga redovisade kategorierna har antalet hemarbetande inte ökat. I stället tycks det här handla om en minskning - vilket möjligen är något förvånande.

Den utveckling jag nu beskrivit innebär att det uppstått en större dold arbetslöshet när arbetsmarknaden försämrats - folk har helt enkelt lämnat arbetskraften. Alldeles dold är ändå inte denna arbetslöshet; arbetskraftsundersökningarna har vissa data om den. Man frågar nämligen personer som inte är sysselsatta och inte räknas som öppet arbetslösa om de kunnat och velat ta ett arbete. De som svarar ja på dessa i och för sig hypotetiska frågor räknas som latent arbetssökande.

Det finns ytterligare en dimension av arbetslösheten som redovisas i arbetskraftsundersökningarna. Den avser individer som har arbete men som av arbetsmarknadsskäl arbetar mindre än de skulle vilja. Dessa personer räknas som undersysselsatta.

Arbetskraftsundersökningarna särskiljer med andra ord tre dimensioner av arbetslösheten vilka fångas med beteckningarna (öppet) arbetslösa, undersysselsatta och latent arbetssökande. De båda senare kategorierna redovisas sällan i de massmediala beskrivningarna av vad som händer på arbetsmarknaden. I tabell 4 får vi dock uppgifter om de tre kategorierna på en och samma gång.

I genomsnitt fanns det i Sverige bara ca 75000 öppet arbetslösa 1990. Tre respektive fyra år senare var motsvarande tal 356000 och 340000 . När vi lägger till de båda övriga arbetslöshetsdimensionerna stiger siffrorna för 1990 till 304000 och för 1993 och 1994 till hela 832000 respektive 882 000. En intressant aspekt är att för de två senare åren kastas könsproportionerna om: Kvinnornas andel blir större än männens. Skälet till detta är att det främst är 
Tabell 4

Ej utnyttjat arbetskraftsutbud 1990, 1993 och 1994. Tusental personer.

$\begin{array}{lccc} & 1990 * & 1993 & 1994 \\ \text { Arbetslösa } & 75 & 356 & 340 \\ \text { män } & 40 & 219 & 202 \\ \text { kvinnor } & 36 & 137 & 138 \\ & & & \\ \text { Undersysselsatta } & 192 & 336 & 358 \\ \text { män } & 63 & 107 & 109 \\ \text { kvinnor } & 130 & 229 & 249 \\ & & & \\ \text { Latent arbetssökande } & 37 & 140 & 184 \\ \text { män } & 18 & 75 & 99 \\ \text { kvinnor } & 19 & 65 & 85 \\ \text { Totalt } & & & \\ \text { män } & 304 & 832 & 882 \\ \text { kvinnor } & 121 & 401 & 410 \\ & 185 & 431 & 472\end{array}$

* Siffrorna för 1990 är justerade efter de förändringar som gjorts i arbetskraftsundersökningarna fr.o.m 1993.

Källor:»Sysselsättning och...« 1993 och Arbetskraftsundersökningen 1993 och 1994.

kvinnorna som arbetar deltid och vill ha längre arbetstid. År 1994 stod männen för ca 59 procent av den öppna arbetslösheten men för bara ca 46 procent av den totala arbetslösheten om vi räknar den på det sätt som sker i tabell 4.

Det outnyttjade arbetskraftsutbudet redovisas också i timmar per vecka. År 1990 stod de öppet arbetslösa för ungefär två och en halv miljoner outnyttjade timmar per vecka, men räknar vi in uppgifterna för de undersysselsatta och de latent arbetssökande kommer vi upp i fem och en halv miljoner. Fyra år senare var talen för de öppet arbetslösa ca 13,1 miljoner timmar och för de tre kategorierna tillsammans ca 23,8 miljoner. Antalet faktiskt arbetade timmar per vecka var år 1994 i genomsnitt drygt 122 miljoner och det outnyttjade arbetskrafts- utbudet motsvarade då alltså ganska precis en femtedel därav.

Förutom den arbetslöshet som här redovisats ska också påminnas om att ett stort antal människor är indragna i arbetsmarknadspolitiska sysselsättnings- och utbildningsåtgärder. Den aktiva arbetsmarknadspolitiken har inte upphört under 1990-talet. Alla politiska partier av någon betydelse har varit överens om att försvara den s.k. arbetslinjen som innebär att människor vid arbetslöshet ska ha arbete eller utbildning snarare än kontantunderstöd. Syftet med arbetslinjens åtgärder är att folk inte ska ställas utanför arbetsmarknaden, men de hamnar förstås likväl i marginalen.

De människor som sätts i utbildning eller jobb genom arbetsmarknadsmyndigheternas försorg har till följd av det försämrade 
arbetsmarknadsläget och den bibehållna aktiva arbetsmarknadspolitiken blivit avsevärt fler. Detta har skett parallellt med tillväxten av arbetslösheten som därigenom bromsats en del. Antalet personer i viktigare arbetsmarknadspolitiska åtgärder steg från i genomsnitt ca 140000 år 1990 till ca 308000 personer 1994 (se Furåker 1995). Under perioden har vissa åtgärder tillkommit såsom ungdomspraktik, ALU och utbildningsvikariat. Den största expansionen avser annars arbetsmarknadsutbildningen, men även antalet personer som omfattas av beredskapsarbete och rekryteringsstöd har ökat avsevärt.

År 1994 var som sagt de öppet arbetslösa, undersysselsatta och latent arbetssökande tillsammans i genomsnitt ungefär 882000 personer (tabell 4). Om vi därtill lägger antalet individer i arbetsmarknadspolitiska åtgärder, dvs. 308000 , kommer vi upp i nästan 1,2 miljoner människor som helt eller delvis stod utanför den ordinarie arbetsmarknaden trots att de sade sig vilja ha arbete eller mer arbete. Motsvarande tal för 1990 blir bara 444 000. Ökningen är således dramatisk: på fyra år mer än två och en halv gånger fler individer $i$ en sådan marginaliserad position. Vi ska vara medvetna om att den marginaliserade gruppen inte som helhet ingår i arbetskraften, men den motsvarade 1994 faktiskt mer än en fjärdedel därav. Problemen på arbetsmarknaden är med andra ord betydligt större än vad de relativa arbetslöshetstalen indikerar.

En viktig aspekt på arbetslösheten är dess varaktighet. Om individer går utan arbete vecka efter vecka är risken stor att deras situation successivt försämras. Utbildnings- och yrkesmässig kompetens kan gå förlorad och det blir ofta svårt att komma tillbaka i arbete om man länge varit sysslolös. Vidare ökar riskerna för negativa hälsoeffekter och andra problem (se bl.a. Halvorsen 1994, kap 4 och 5). I efterkrigstidens Sverige har man lyckats tämligen väl med att begränsa arbetslöshetens varaktighet dels genom en allmänt god efterfrågan på arbetskraft, dels genom olika slags arbetsmarknadspolitiska åtgärder som vanligen satts in ganska snabbt. Nu förefaller den lyckliga tiden vara över.

Stigande långtidsarbetslöshet innebär en numerär tillväxt av den grupp som är mest alienerad från arbetslivet. Konsekvenserna av detta kan bli allvarliga på längre sikt genom att det etableras subkulturer där människor står utanför allmänt omfattade värderingar, normer och livsmönster. Som framgår av tabell 5 varade pågående arbetslöshet år 1990 i genomsnitt knappt 15 veckor. År 1993 rörde det sig om drygt 23 veckor och 1994 om nästan 28 veckor. Männens tal ligger högre än kvinnornas, men skillnaden är inte så stor. Däremot är skillnaderna mellan olika åldersgrupper betydande. De yngres arbetslöshet uppvisar betydligt kortare varaktighet än vad vi finner för de övriga och framför allt för de äldre. Samtidigt har avståndet mellan de yngre och de äldre krympt.

Andelen långstidsarbetslösa (arbetslösa minst sex månader) har också ökat - från 0,3 procent av arbetskraften 1990 till 2,6 procent 1993 och 3,1 procent 1994 (med något högre tal för männen). Det rör sig alltså om en mångdubbling av nivån. På sätt och vis kan 1993 och 1994 års siffror tyckas rätt låga, men vi ska komma i håg att före den nuvarande försämringen på arbets- 
Tabell 5

Pågående arbetslöshets varaktighet samt andel längtidsarbetslösa (minst 6 månaders arbetslöshet) i arbetskraften år 1990, 1993 och 1994. Veckor och procent.

$\begin{array}{lccc} & 1990 * & 1993 & 1994 \\ \text { Antal veckor } & 14,7 & 23,4 & 27,7 \\ \text { män } & 15,3 & 24,6 & 29,4 \\ \text { kvinnor } & 14,2 & 21,4 & 25,3 \\ & & & \\ 16-24 \text { år } & 9,6 & 18,8 & 21,8 \\ 25-54 & 14,5 & 23,9 & 28,4 \\ 55-64 & 31,1 & 33,6 & 37,4 \\ & & & \\ \text { Andel långtidsarbetslösa } & & & 3,1 \\ \text { av arbetskraften (\%) } & 0,3 & 2,6 & 3,7 \\ \text { män } & 0,3 & 3,3 & 2,4 \\ \text { kvinnor } & 0,2 & 1,9 & \\ & & & \\ \text { * Siffrorna för de långtidsarbetslösas andel av arbetskraften är justerade efter de förändringar som gjorts i arbets- } \\ \text { kraftsundersökningarna fro.m |993;i övrigt har inga justeringar skett. }\end{array}$

Källor:»Sysselsättning och...« 1993 och Arbetskraftsundersökningen 1993 och 1.994.

marknaden betraktades sådana tal som höga nivåer för den totala arbetslösheten (dvs. inklusive de korttidsarbetslösa).

Arbetslösheten har sålunda på kort tid blivit ett allvarligt problem på den svenska arbetsmarknaden. Den förändring och försämring som ägt rum under 1990-talets första år saknar motsvarighet under efterkrigstiden. I dag står stora grupper utanför den ordinarie arbetsmarknaden med allt vad det kan innebära för de drabbade individerna: lägre inkomster, lägre självförtroende, mindre inflytande i samhället, försvagad framtidstro och större risker vad gäller hälsa och välbefinnande. Klassamhället håller på att återfå sina skarpare konturer från förr i tiden - om än under annorlunda omständigheter.

När det gäller arbetslöshetens fördelning mellan olika grupper finns åtskilligt att säga. Vi har redan sett att männen har högre arbetslöshetstal än kvinnorna - något som sammanhänger med att nedgången i första hand rört industrin och byggnadsverksamheten. Om den nu inledda - men hittills tämligen begränsade - uppgången $i$ industrin skulle fortsätta samtidigt som den offentliga sektorn fortsätter att skäras ned kan den bilden förändras. Då kan vi om några år finna högre tal för kvinnorna.

Ålder är en annan viktig faktor. Det är framför allt ungdomarnas arbetslöshetstal som har stigit under senare år. Men också den äldre arbetskraften har fått känna av det försämrade arbetsmarknadsläget och många äldre har blivit förtidspensionerade. Vidare ska understrykas att arbetslösheten i huvudsak är ett arbetarklassfenomen (Fur- 
åker 1995). Visserligen har arbetslöshetstalen ökat för både arbetare och tjänstemän, men skillnaden de båda kategorierna emellan är tydlig och den har förstärkts på 1990talet.

Ett mycket oroande inslag i de senaste årens utveckling är ökningen av arbetslöshetstalen för icke-nordiska utländska medborgare. Sedan 1990 har dessa tal stigit från ca 5 till 27-28 procent (Furåker 1995). Därmed skiljer de sig kraftigt åt från vad vi finner för svenska och övriga nordiska medborgare. Det finns en tydlig etnisk hierarki där svenskarna klarar sig bäst och de ickenordiska medborgarna drabbas värst.

Man behöver inte tveka om vilka kategorier som i första hand marginaliseras. Vi vet också att det finns en mer eller mindre utbredd misstänksamhet mot dem som uppbär arbetslöshetsersättning. Många ger uttryck för åsikten att dessa egentligen skulle kunna få ett jobb om de bara ville (jfr Svallfors 1995). Den misstänksamheten kan lätt förstärkas genom att de personer som får ersättning har ett annat etniskt ursprung. Här finns en grogrund för tilltagande sociala spänningar framöver.

Tyvärr finns det i dag inga starka skäl att tro att arbetslösheten är ett snabbt övergående problem. Den förefaller visserligen vara på nedåtgående, men det är inte självklart att vi mer varaktigt kan komma tillbaka till de gamla nivåerna. I vår europeiska omgivning ser det ofta lika illa ut och på många håll är det värre. Om Sverige ska klara sig bättre krävs det något annat än en anpassning efter förhållandena i Europeiska unionen.

\section{Försörjningstrycket omfördelas}

Vad har nu de senaste årens utveckling fört med sig? Det finns, som torde ha framgått här, många sätt att räkna på, men hur vi än gör finner vi tämligen dramatiska förändringar. Låt oss ett ögonblick återvända till siffrorna över sysselsättningsintensiteten i tabell 1 och läsa dem nåt andra hållet»,dvs. se efter hur stor andel av befolkningen i åldern 16-64 år som saknade förvärvsarbete. År 1990 stod 17,6 procent av den aktiva befolkningen utan jobb och motsvarande tal 1994 var 28,6 procent. Detta senare år var det med andra ord hela 11 procentenheter fler som måste få sin försörjning via något annat än förvärvsarbete.

Till följd av denna utveckling har trycket på de alternativa försörjningskällorna ökat påtagligt. Från de av Statistiska centralbyrån reviderade talen för 1990 kan vi räkna ut att de 17,6 procenten icke sysselsatta betyder ca 950000 personer ("Sysselsättning.... 1993). Motsvarande beräkning för de 28,6 procenten utan förvärvsarbete 1994 ger ett tal om drygt 1570000 individer. Det rör sig med andra ord om ca 620000 människor fler som 1994 var tvungna att överleva på annat sätt. En så stor förändring måste sätta tydliga spår $i$ befintliga försörjningsmönster.

Av de övriga försörjningskällorna är det egentligen bara familjen och välfärdsstaten som kan spela någon viktigare roll som alternativ. Välfärdsstaten träder normalt in och tillhandahåller ekonomiskt stöd åt dem som söker jobb men inte kan få något. Under den fyraårsperiod vi här talar om ökade det genomsnittliga antalet personer med ersätt- 
ning från arbetslöshetskassa rejält - från drygt 66.000 till närmare 332.000 (Historiska tabeller 1994). Det betyder en uppgång med omkring 265000 individer. Under samma period steg det genomsnittliga antalet mottagare av kontant arbetsmarknadsstöd från i runda tal 8000 till 38000 , dvs. med ungefär 30000 (uppgifterna har inhämtats per telefon från Arbetsmarknadsstyrelsen). Totalt ger detta en ökning med omkring 295000 bidragstagare. Tillväxten av antalet icke sysselsatta i yrkesaktiv ålder om ca 620000 personer (se ovan) täcks alltså inte ens till hälften via arbetslöshetskassorna och det kontanta arbetsmarknadsstödet.

Det är svårare att få grepp om villkoren för de övriga 325000 fler personerna utan arbete. Några tidigare redovisade fakta kan dock ge viss vägledning. Mellan 1990 och 1994 steg antalet studerande med ca 170000 personer. Somliga av dessa har studiemedel, medan andra är föremål för arbetsmarknadspolitiska utbildningsinsatser och finansieras genom utbildningsbidrag. Individer i ALU (närmare 45000 år 1994) försörjs emellertid via arbetslöshetskassa eller kontant arbetsmarknadsunderstöd. Personer som berörs av arbetsmarknadspolitikens sysselsättningsåtgärder räknas som förvärvsarbetande och är därför inte av intresse här.

Vidare vill jag påminna om ökningen av antalet förtidspensionärer; beståndet växte under den aktuella fyrårsperioden med kanske 55000 personer (se "Förtidspensioner..." 1995). En del av dem som har lämnat arbetskraften har dock fått andra typer av pension.

Den viktiga slutsats som följer av denna genomgång är att välfärdsstaten uppenbarli- gen i någon mening tar hand om de flesta av dem som ställs utan arbete. Jämförelsen mellan 1990 och 1994 visar följande: Under det senare året var det ca 295000 fler personer som fick arbetslöshetsunderstöd, ca 125000 fler som studerade utan att ha finansiering från arbetslöshetskassa eller kontant arbetsmarknadsunderstöd och ca 55000 fler som uppbar förtidspension. Lägger vi ihop dessa tal kommer vi upp i omkring 475000 individer. Av ökningen om ungefär 620000 personer i yrkesaktiv ålder utan förvärvsarbete återstår då drygt 145000 om vilka vi inte kan säga så mycket.

Även om den svenska välfärdsstaten fortfarande är jämförelsevis generös så blir det ekonomiska avbräck för dem som drabbas av arbetslöshet. De arbetslösa har det generellt sett sämre än de som har jobb och det samma gäller för individer som hamnar i arbetsmarknadspolitiska åtgärder av olika slag. Några blir också utförsäkrade. Åtskilliga har alltså fått försämrad ekonomi. Antalet hushåll med socialbidrag har stigit om än inte lika mycket som man kanske kunde förvänta sig. Tyvärr finns inte 1994 års siffror tillgängliga ännu, men mellan 1990 och 1993 ökade antalet socialbidragshushåll med ca 96000 och antalet berörda individer med ca 154000 ("Socialbidrag.... 1994). Också bidragstiderna steg mellan de båda nämnda åren - från i genomsnitt 4,1 till 4,6 månader.

Det försämrade sysselsättningsläget har åsamkat välfärdsstaten ökade utgifter i flera avseenden. Det första man kommer att tänka på är förstås utgifterna för arbetslöshetsförsäkringen och för de arbetsmarknadspolitiska åtgärderna. Kostnaderna för dessa insatser har på några år skjutit kraf- 
tigt i höjden. Samtidigt har emellertid kostnaderna för sjukförsäkringen minskat, både därför att färre nu är frånvarande på grund av sjukdom och därför att ersättningsnivåerna sänkts.

Arbetslösheten åstadkommer även ett intäktsbortfall för den offentliga sektorn genom att färre har arbete och betalar inkomstskatt. En annan konsekvens är minskad konsumtion vilket bl.a. betyder lägre momsintäkter. Likaså har olika ingrepp i skattesystemet (den stora skattereformen, sänkt kapitalbeskattning m.m.) medfört krympta resurser för den offentliga sektorn. Sammantaget har välfärdsstaten fått det svårare att klara av sina uppgifter - parallellt med att dessa blivit tyngre till följd av den ökade arbetslösheten. Statens budgetunderskott har snabbt blivit det politiskt allt mer överskuggande problemet. Det är därför inte överraskande att bidragsnivåerna i socialförsäkringssystemen nu skärs ner.

Vilken roll spelar då familjen? Ja, av tabell 3 ovan kan vi dra slutsatsen att kvinnor i vart fall inte har återvänt till hemmen. Antalet hemmafruar tycks fortsätta minska trots det besvärliga konjunkturläget. Ingenting tyder på att det gamla talet om att kvinnorna får återvända till spisen i lågkonjunkturer har någon giltighet. Under välfärdsstatens utbyggnadsperiod steg för övrigt kvinnornas arbetskraftsdeltagande successivt oavsett hur konjunkturen utvecklades.

Även om kvinnorna inte återvänt till spisen har det med den allmänna nedgången skapats ett ökat tryck på familjen. Tills vidare vet vi inte så mycket konkret om effekterna. Antalet studerande har ökat och många ungdomar verkar bo kvar hemma längre än vad de gjorde för bara några år se- dan (se "Drömmen..." 1995). De får nog också i större utsträckning än tidigare annat stöd av sina föräldrar. Problemet med familjen som försörjningsgarant är att den ger individerna så olika villkor beroende på den samhälleliga fördelningen av livets goda. Privata lösningar av det slaget innebär att existerande klassklyftor tillåts slå igenom.

Beträffande de övriga försörjningsmekanismerna ska påminnas om att de bara avser små kategorier. En avsutten finansminister lär ha önskat att alla skulle ha en årslön på banken. Dit är det faktiskt mycket långt. Få har så stora tillgångar att de under någon längre tid kan avstå från förvärvsarbete; förmögenhetsbildningen bland enskilda är ett marginellt fenomen när vi talar om försörjning för befolkningen som helhet. Privata försäkringar, välgörenhet m.m. kan självfallet inte heller lösa några problem - i varje fall inte på ett fördelningspolitiskt acceptabelt sätt.

I och med nedrustningen av välfärdsstaten vältras allt större börda över på familjer och enskilda individer. Huruvida eller i vilken utsträckning dessa kan parera de ökade påfrestningarna är oklart. I en första fas har många ändå vissa marginaler att ta av, men vad händer sedan? När de alternativa försörjningsmekanismerna inte tillräckligt kan kompensera bortfallet av förvärvsinkomster blir konsekvensen sänkt levnadsstandard och kanske direkt fattigdom för somliga. Om inte utvecklingen vänder måste vi räkna med tilltagande inkomstklyftor och en återgång till ett mer utpräglat klassamhälle. Finns det då ingenting som kan hejda den processen? Svaret är nog att det krävs ett brett och kraftfullt motstånd, men frågan är varifrån ska det komma. 


\section{Referenser}

Arbetskraftsundersökningen. Årsmedeltal (olika år). Statistiska centralbyrån, Stockholm.

Castles, Francis G (ed.) (1989): The Comparative History of Public Policy. Polity Press, Cambridge.

„De svenska arbetskraftsundersökningarna (AKU) (1993). Bakgrundsfakta till arbetsmarknads- och utbildningsstatistiken. 1993:1. Statistiska centralbyrån, Stockholm.

"Drömmen om eget hus". Vår bostad nr 81995.

Esping-Andersen, Gøsta (1990): The Three Worlds of Welfare Capitalism. Princeton University Press, Princeton, New Jersey.

Furåker, Bengt (1991): „The Swedish Model Since the Early 1980s. " I Hans-Jeppe Jeppesen \& Jens Lind (eds.): Changes in the Labour Market and Industrial Relations in Europe. University of Aalborg. Carma Yearbook.

Furåker, Bengt (1995): „Arbetslösheten i Sverige - en bild av 1990-talets utveckling samt några frågor för forskningen". I Anders Gullberg \& Martin Börjeson (red.): Arbetslöshet bland ungdomar - en diskussion om rådande kunskapsläge och utkast till framtida forskningsprojekt. Epidemiologiskt centrum, Socialstyrelsen).

Författning (grundlag) för Socialistiska sovjetrepublikernas union. Förlaget Progress, Moskva 1980.

"Förtidspensioner. Utbetalade i december 1994" (1995). Riksförsäkringsverket informerar. Statistikinformation Is-I 1995:6.

Ginsburg, Norman (1992): Divisions of Welfare. A Critical Introduction to Comparative Social Policy. Sage, London.

Halvorsen, Knut (1994): Arbeidsløshet og arbeidsmarginalisering-levekair og mestring. Universitetsforlaget, Oslo.

Historiska tabeller. Uppgifter to m 1: a halvåret 1994 (1994). Arbetsmarknadsstyrelsen, Solna.

Kolberg, Jon Eivind (ed.) (1992): The Study of Welfare State Regimes. M E Sharpe, New York.

"Nybeviljade förtidspensioner 1971-1994"(1995). Riksförsäkringsverket informerar. Statistikinformation Is-I 1995:2.

Olofsson, Gunnar (1993): „Det svenska pensionssystemet 1913-1993: historia, struktur och konflikter. Arkiv nr 58-59.

Palme, Joakim (1990): Pension Rights in Welfare Capitalism. The Development of Old-Age Pensions in 18 OECD Countries 1930 to 1985. Institutet för social forskning, Stockholms universitet.

"Socialbidrag under 1993. Definitiva uppgifter" (1994). Statistiska meddelanden. S 33 SM 9402.

"Sysselsättning och arbetslöshet 1970-1992 (1993). Information från arbetskraftsundersökningarna 1993:1. Statistiska centralbyrån, Stockholm.

Svallfors, Stefan (1995): „Oförändrat stöd för offentlig välfärd». Välfärdsbulletinen nr 1. Statistiska centralbyrån, Stockholm. 


\section{Summary}

\section{Gainful employment and support}

This article deals with the deterioration of the labour market in Sweden in the 1990s and its consequences for the ways in which people make their livelihood. Although gainful employment is the fundamental source of support, nobody can work all his or her life and some cannot do it at all. There is thus a need for other means of support, and the alternative mechanisms include the family, various kinds of property, the welfare state and private insurances. Of course, very few can make a living from their property. Those supported by the family are above all children, young people and housewives. In modern Sweden the welfare state has become increasingly important in providing for various categories of people: the elderly, the handicapped, the unemployed, etc. Because of this the private insurance sector has acquired a less salient role.

In the early 1990s more than half a million jobs disappeared from the Swedish labour market and unemployment multi- plied. Moreover, lots of people left, or never entered, the labour force. Those outside the labour force increased in numbers even more than the unemployed. There was also a rapid growth in the number of participants in labour market training, jobcreation programmes, etc. As a result of this development fewer people can now expect to get a job in the ordinary labour market. The welfare state provides a living for many, but since higher unemployment means higher expenditures and lower incomes, this becomes increasingly difficult. If employment cannot be brought back to its previous level it seems likely that the already reduced benefits for the unemployed (and others in need of welfare state support) will remain low. There is thus growing financial pressure upon many families and individuals. Consequently, we may expect increasing poverty and widening social differences in Sweden. 